\title{
Neogene decapod crustaceans from the Caribbean of Colombia
}

\author{
Hermann D. Bermúdez, Francisco A. Vega-Sandoval, Francisco J. Vega
}

Hermann D. Bermúdez

440 Hemlock Rd. St. George, VT, 05495.

USA.

\section{Francisco A. Vega-Sandoval}

Licenciatura en Ciencias de la Tierra,

Facultad de Ciencias, Universidad Nacional

Autónoma de México, Campus Juriquilla,

Querétaro, C.P. 76230, Mexico.

\section{Francisco J. Vega}

vegver@unam.mx

Instituto de Geología, Universidad Nacional Autónoma de México, Ciudad Universitaria, C.P. 045 10, CDMX, Mexico.
BOL. SOC. GEOL. MEX. 2017

VOL. 69 NO. 3

P. $655-668$

\section{ABSTRACT}

An abundant and diverse assemblage of decapod crustaceans from the Neogene (Miocene to Pliocene) from the Las Perdices and Tubará formations in San Jacinto Fold Belt (Colombian Caribbean) is here reported. Found in shallow marine and paralic sediments, specimens of the following species are identified: Callianassidae, Neocallichirus scotti (Brown and Pilsbry, 1913), Glypturus toulai (Rathbun, 1919), Petrochirus bouvieri Rathbun, 1919, Hepatus lineatinus Collins and Todd in Todd and Collins, 2005, Palaeopinixa perornata Collins and Morris, 1976, Persephona enigmatica Collins and Todd in Todd and Collins, 2005, Microphrys sp., Necronectes proavitus (Rathbun, 1918), Scylla sp., Euphylax maculatus Collins and Todd in Todd and Collins, 2005, and Eurytium sp. All of these species indicate a correlation with other Caribbean crustaceans from the Neogene, mainly of Panama, Costa Rica, and Venezuela. The facies association and decapod assemblage suggest shallow marine environments for the Neogene units of this area of Caribbean coast of Colombia.

Keywords: Crustacea, Decapoda, Neogene, Garibbean, Colombia.

\section{RESUMEN}

Se reporta una diversa y abundante asociación de crustáceos decápodos del Neógeno (Mioceno al Plioceno) de las formaciones Las Perdices y Tubará en el Cinturón Plegado de San Facinto (Caribe colombiano). En sedimentos marinos y parálicos, fueron encontrados ejemplares de las especies: $\mathrm{Ca}^{-}$ llianassidae, Neocallichirus scotti (Brown and Pilsbry, 1913), Glypturus toulai (Rathbun, 1919), Petrochirus bouvieri Rathbun, 1919, Hepatus lineatinus Collins and Todd in Todd and Collins, 2005, Palaeopinixa perornata Collins and Morris, 1976, Persephona enigmatica Collins and Todd in Todd and Colins, 2005, Microphrys sp., Necronectes proavitus (Rathbun, 1918), Scylla sp., Euphylax maculatus Collins and Todd in Todd and Collins, 2005, y Eurytium sp. Todas estas especies indican una correlación con otras asociaciones caribeñas de crustáceos del Neógeno, principalmente de Panamá, Costa Rica, y Venezuela. Las asociaciones de facies y el conjunto de crustáceos sugieren paleoambientes marinos someros para las unidades neógenas de esta área de la costa caribe de Colombia.

Palabras clave: Crustacea, Decapoda, Neógeno, Caribe, Colombia. 


\section{Introduction}

Neogene shallow marine lithostratigraphic units are found at the San Jacinto Fold Belt (SJFB), mainly at the Luruaco anticlinorium, placed between Cartagena de Indias and Barranquilla (N Colombia), where fossiliferous horizons include abundant mollusks, reported by several authors (Pilsbry and Brown, 1917; Anderson, 1927, 1929; Weisbord, 1929). Recently, more detailed stratigraphic and paleontological reports indicate a more precise age and defined paleoenvironments (Pineda-Salgado et al., 2013). This is the first record of Neogene crustaceans from the Colombian Caribbean. Most of the crustacean specimens have a good preservation, including both isolated articles and articulated carapaces, some with fine details of the cuticle. The most abundant crustaceans are callianassoids and portunoids.

\subsection{LOGATION AND GEOLOGICAL SETTING}

The study area is located on the central portion of the Caribbean coast of Colombia, in the Luruaco region (W area of Atlántico department), $50 \mathrm{~km}$ SW of Barranquilla (Figure 1), approximately 700 km north of Bogotá, D.C. The crustacean specimens from the Las Perdices Formation were collected in outcrops located $1 \mathrm{~km} \mathrm{NE}$ of Hibacharo town, Atlántico (Figure 1). The sampled horizons correspond to the SE plunge of the Tubará syncline, at the top of the unit, composed mainly by shales and marls. Crustacean specimens from the Tubará Formation were found along roadcuts that leads to the municipio de Tubará, Atlántico, at the W flank of the Tubará syncline, in marls with intercalations of sandstone and conglomerate.

\subsection{STRATIGRAPHY}

The Luruaco anticlinorium includes Neogene sediments of the Las Perdices, Piojó and Tubará formations (Figure 2). The Las Perdices Formation (Upper Oligocene - middle Miocene) consists mainly of mudstone, marl and gray shale, with a few horizons with calcareous concretions, and thin sandstones and siderite lenses near the top. The Piojó Formation (middle - upper Miocene) consists of very thick sandstone beds at the base, followed by thick layers of mudstone and shale, intercalated with sandstone beds at the top. The Tubará Formation (upper Miocene - Pliocene) consists of conglomerate and sandstone at the base, followed by mudstone and fossiliferous sandstone, with abundant layers of coquina. The fine-grained sequences include abundant macroinvertebrate fossils, mainly mollusks, echinoderms and annelid tubes, as well as foraminifera and fish remains. These fossils have been partially studied by several authors: Anderson (1929), Weisbord (1929), Barrios (1960), Bermúdez et al. (2009), Pineda-Salgado et al. (2013), Vega and Bermúdez (2015).

Crustacean specimens were collected near the top of the Las Perdices Formation, within concretions in a thick, dark-gray massive claystone, with coal fragments, and bivalves, gastropods, polychaete tubes, and echinoids. Based upon calcareous nannoplankton, foraminifera and pollen biostratigraphy, these layers were deposited during early to middle Miocene as muds deposited in low-energy, anoxic environments with occasional influence of marine water. These conditions have been shown to cause stress and prevent a presence of infaunal organisms (Maceachern et al., 2005; Bhattacharya and MacEachern, 2009). Presence of siderite reinforce the paleoenvironmental interpretation of a reducing environment in fluvial to estuarine facies with abundant vegetal remains (Berner, 1971), where oxygen is removed by the influence of anoxic bacteria, causing siderite precipitation and presence of methane (Berner, 1981; Middleton and Nelson, 1996; Laenen and De Craen, 2004). This prevents the presence of filter-feeding organisms (Coates and MacEachern, 2007), as seen in most coastal lagoons.

Crustacean remains are more abundant and diverse within the fossiliferous beds of the Tubará Formation, found near the top of Pliocene age stratigraphic unit (Molinares et al., 2007), within thin to thick fossiliferous dark-gray shale layers, 


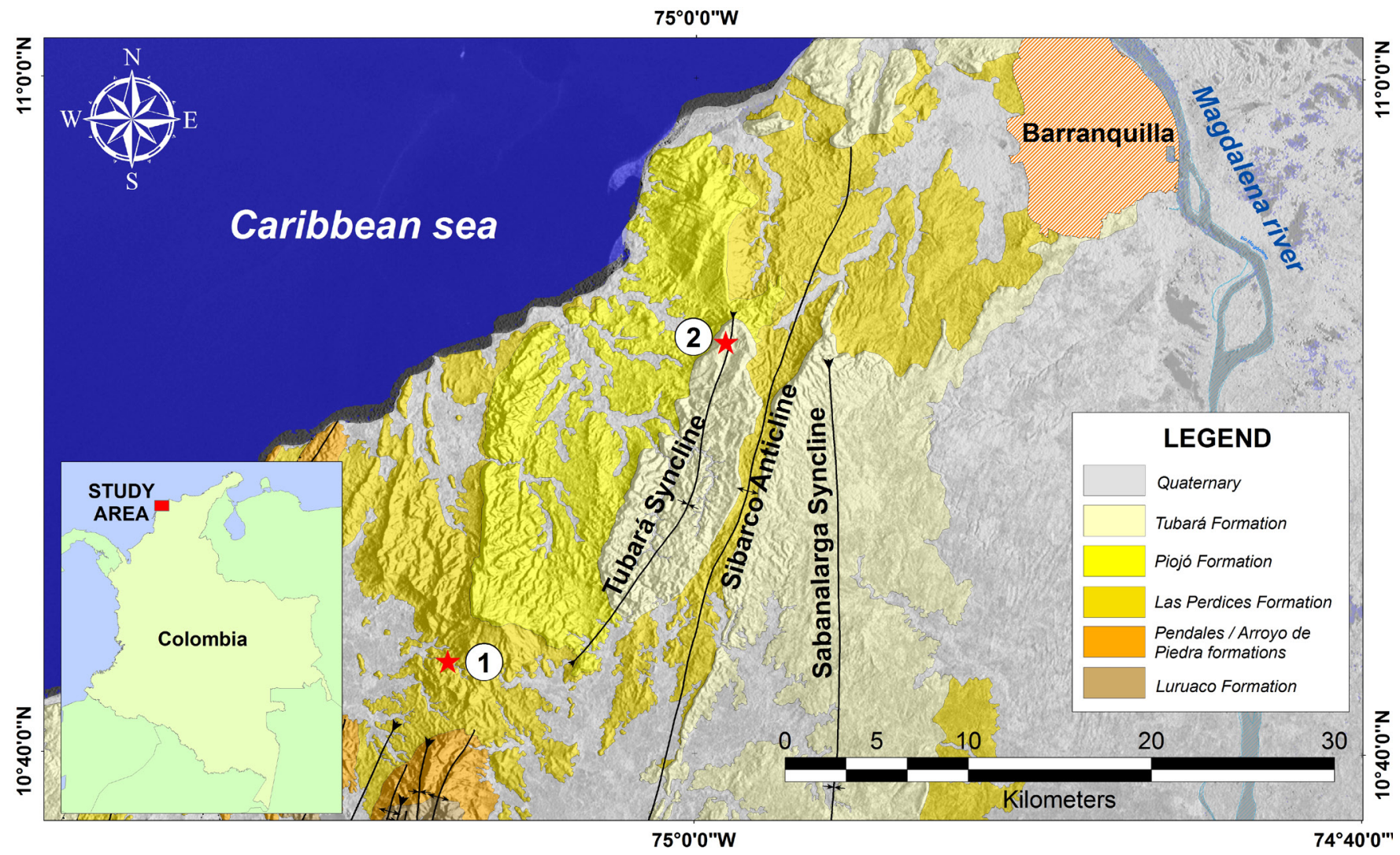

Figure 1 Location map of the Luruaco anticlinorium, north region of SJFB province, Caribbean of Colombia, with position of fossil localities: (1) Hibacharo area, Las Perdices Formation, (2) Tubará area, Tubará Formation.

interbedded with thick, cross-bedded, grayish-yellow, lithic sandstone and coquinoid beds (including gastropods, bivalves, cirripedians, polychaete tubes, shark teeth and turtle remains). Storm accumulations of bioclasts include crustacean remains at the top of the Tubará Formation, in a lithology dominated by sandstone, whereas more complete crab remains are found in fine sandstone, suggesting low energy and fast burial, as indicated by the presence of articulated corpses and molts.

\section{Material}

The study specimens are deposited in the Paleontological Collection of the Universidad Nacional de Colombia, Facultad de Ciencias, Departamento de Geociencias, Bogotá D.C., Colombia, under catalog numbers UN-DG-CR.
Systematic order is mainly based on de Grave et al. (2009).

\section{Systematic paleontology}

Order Decapoda Latreille, 1802

Infraorder Axiidea de Saint Laurent, 1979

Superfamily Callianassoidea Dana, 1852

Family Callianassidae Dana, 1852

Figure 3.1

Description. Merus elongated, semirectangular, with sharp longitudinal keel on outer surface; carpus narrow, one-third the length of carpus, smooth outer surface; propodus semirectangular, as high as carpus. The specimens are incomplete to offer a more specific identification. 


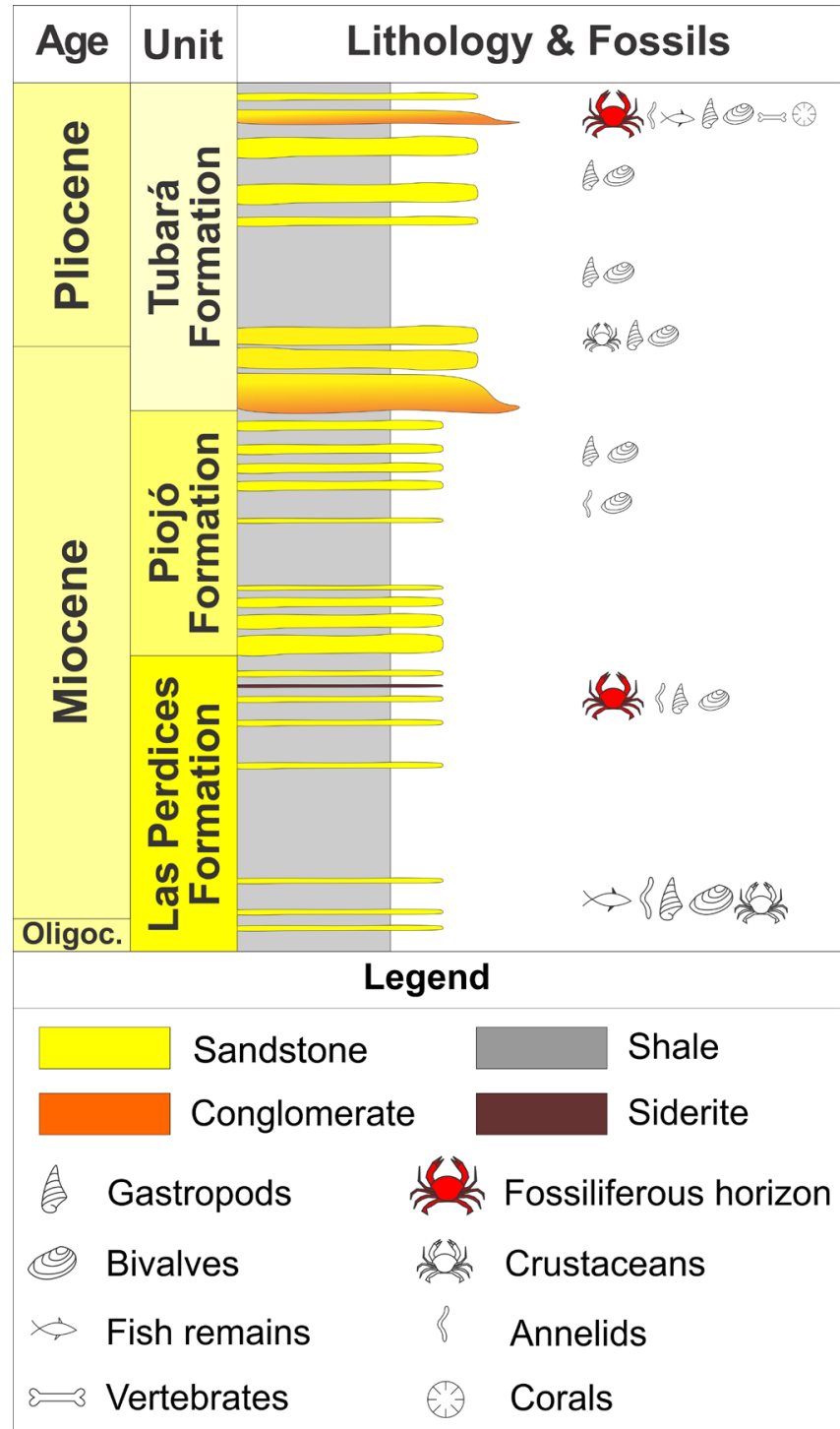

Figure 2 Stratigraphic section of Neogene units of Luruaco anticlinorium area (North SJFB province), showing position of horizons containing crustacean specimens.

Material. Two incomplete left chelipeds, UNDG-CR-033 and UN-DG-CR-034. Tubará Formation, Upper Miocene-Pliocene.

Measurements. UN-DG-CR-033, length = $33.2 \mathrm{~mm}$, height $=14.2 \mathrm{~mm}$; UN-DG-CR-034, length $=35.4 \mathrm{~mm}$, height $=16.8 \mathrm{~mm}$.

Comments. Callianassidae remains are reported from the middle to Late Miocene of Panama (Rathbun, 1918).
Genus Neocallichirus Sakai, 1988

Neocallichirus scotti (Brown and Pilsbry, 1913)

Figure 3.2, 3.3

Description. Right propodus subquadrate, upper and lower margins slightly divergent distally, dorsal and ventral margins smooth, outer surface finely granulated, inner surface smooth; fixed finger elongated, half the length of propodus.

Material. One right propodus, UN-DG-CR-035. Tubará Formation, Upper Miocene-Pliocene.

Measurements. UN-DG-CR-035, left propodus length $=18.2 \mathrm{~mm}$, height $=15.5 \mathrm{~mm}$.

Comments. Right propodus subquadrate, dorsal and ventral margins slightly divergent distally are features that suggest affinity of the Colombian specimens to Neocallichirus scotti, reported also from the Miocene of Panama (Culebra and Gatun formations) (Rathbun, 1919).

\section{Subfamily Callichirinae Manning and Felder, 1991 \\ Genus Glypturus Stimpson, 1866 Glypturus toulai (Rathbun, 1919) \\ Figure $3.4-3.13$}

Description. Merus subovate, with serrate lower margin; propodus nearly as long as high, serrated ventral margin, traces of spines on dorsal margin, inner and outer surfaces smooth, outer portion of anterior margin bears few small tubercles; fixed finger short, with sharp ridge on posterior portion; left dactylus with few tubercles on proximal portion, serrated on distal portion of occlusal surface. Material. Three left propodi (one includes merus), two right propodi and one left dactylus, UN-DG-GR-036 to UN-DG-GR-041. Tubará Formation, Upper Miocene - Pliocene.

Measurements. UN-DG-CR-036, left propodus length $=18.2 \mathrm{~mm}$, height $=15.5 \mathrm{~mm} ; \mathrm{UN}$ DG-CR-037, right propodus length $=17.7 \mathrm{~mm}$, height $=14.6 \mathrm{~mm}$; UN-DG-CR-038, right propodus length $=19.8 \mathrm{~mm}$, height $=11.5 \mathrm{~mm} ; \mathrm{UN}$ DG-CR-039, left propodus length $=19.2 \mathrm{~mm}$, height $=12.5 \mathrm{~mm}$; UN-DG-CR-040, left propo- 


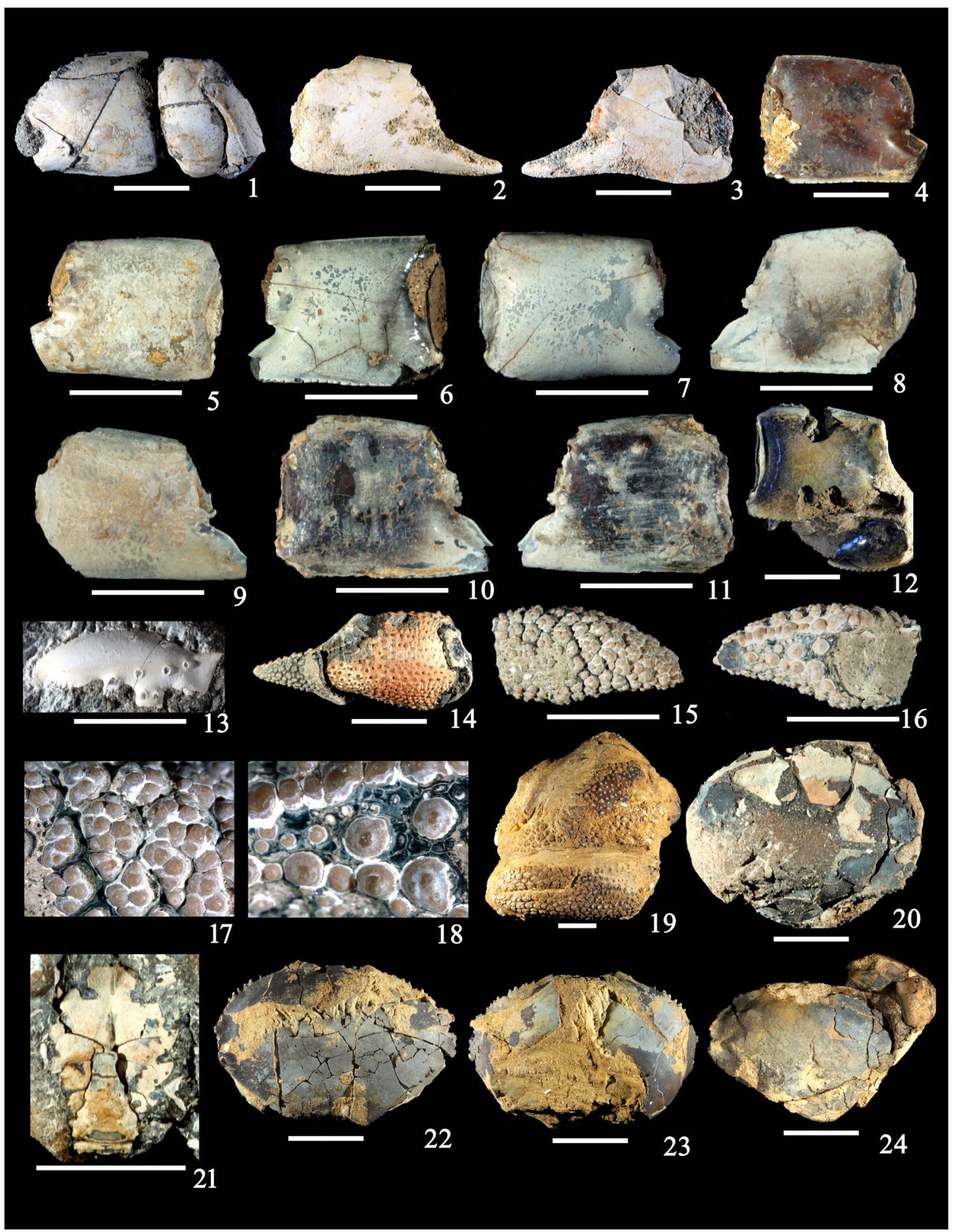

Figure 3 1, Callianassidae, left merus, carpus and propodus UN-DG-CR-033. 2, 3, Neocallichirus scotti (Brown and Pilsbry, 1913), right propodus UN-DG-CR-035. 4-13, Glypturus toulai (Rathbun, 1919), 4, 5, left propodus UN-DG-CR-036; 6-11, right propodus UN-DG-CR-037 to UN-DG-CR-039; 12, left merus and propodus UN-DG-CR-040; 13, left dactylus UN-DG-CR-041. 14-19, Petrochirus bouvieri Rathbun, 1919, 14, left propodus and dactylus UN-DG-CR-042; 15-18, left dactylus and close-ups of cuticle ornament and occlusal surface UN-DG-CR-043; 19, left and right chelae UN-DG-CR-044. 20-24, Hepatus lineatinus Collins and Todd in Todd and Collins, 2005; 20, 21, dorsal and ventral carapace with sternum and abdomen UN-DG-CR-045; 22, 23, dorsal and ventral carapace UN-DG-CR-046; 24, dorsal carapace with right cheliped UN-DG-CR-047. All specimens from the Tubará Formation, Upper Miocene-Pliocene. Scale bars $=10 \mathrm{~mm}$. 
dus length $=20.1 \mathrm{~mm}$, height $=10.3 \mathrm{~mm} ; \mathrm{UN}$ DG-GR-041, left dactylus length $=12.5 \mathrm{~mm}$, height $=5.1 \mathrm{~mm}$.

Comments. Propodus serrated ventral margin and traces of spines on dorsal margin, suggest affinities of the new specimens with Glypturus toulai (Rathbun, 1919), which is reported from the Lower to Upper Miocene of Panama (Culebra and Gatun formations, respectively) (Rathbun, 1919; Todd and Collins, 2005; Hyžný et al., 2013; Klompmaker et al., 2016).

Infraorder Anomura MacLeay, 1838

Superfamily Paguroidea Latreille, 1802

Family Diogenidae Ortmann, 1892

Genus Petrochirus Stimpson, 1858

Petrochirus bouvieri Rathbun, 1919

Figure $3.14-3.19$

Description. Left and right chelae covered by strong tubercles; right chela as long as left chela but twice its height; right propodus curved, dactylus triangular, with short spines on dorsal surface, covered by strong multituberculated ornament, occlusal surface covered by strong granules of diverse size, fixed finger two-thirds the length of dactylus, covered by strong multituberculated ornament; left propodus slightly inflated, propodus slightly shorter than fixed finger, dactylus as long as fixed finger, both densely ornamented with multituberculated granules.

Material. One left propodus, one right dactylus and a pair of chelae, UN-DG-CR-042 to UNDG-CR-044. Tubará Formation, Upper Miocene - Pliocene.

Measurements. UN-DG-CR-042, left propodus length $=24.6 \mathrm{~mm}$, height $=9.8 \mathrm{~mm}$; UN-DGCR-043, right dactylus length $=13.8 \mathrm{~mm}$, width $=7.8 \mathrm{~mm}$; UN-DG-CR-044, pair of chelae, right propodus length $=42.1 \mathrm{~mm}$, height $=24.3 \mathrm{~mm}$, right dactylus length $=18.9 \mathrm{~mm}$, height $=9.7$ $\mathrm{mm}$, left propodus length $=45.2 \mathrm{~mm}$, height $=$ $12.6 \mathrm{~mm}$, dactylus length $=25.7 \mathrm{~mm}$, height $=$ $11.2 \mathrm{~mm}$.
Comments. Shape of chelae and strong tubercles ornamentation indicates affinity of the study specimens with Petrochirus bouvieri, reported also from the Miocene of Panama (Gatun and Chagres formations) (Rathbun, 1919; Todd and Collins, 2005).

Infraorder Brachyura Latreille, 1802

Family Aethroidea Dana, 1851

Genus Hepatus Latreille, 1802

Hepatus lineatinus Collins and Todd in Todd and

Collins, 2005

Figure $3.20-3.24$

Description. Carapace of medium size, transversely subovate, one-third wider than long, multiple short spines on anterolateral margin, about two-thirds the maximum carapace length, posterolateral margin covered by small granules, about half the maximum length, dorsal carapace regions weakly defined, surface covered by fine granules; sternum narrow, last sternites become much narrower; pleon triangular, narrow, fused somites 3 to 5. Right cheliped robust.

Material. Three nearly complete carapaces, one (UN-DG-CR-045) preserving sternum and abdomen and one other preserving right cheliped, UN-DG-CR-045 to UN-DG-GR-047. Tubará Formation, Upper Miocene-Pliocene.

Measurements. UN-DG-CR-045, carapace with sternum and abdomen, length $=32.1 \mathrm{~mm}$, width $=22.5 \mathrm{~mm}$; UN-DG-CR-046, carapace, length $=18.8 \mathrm{~mm}$, width $=32.4 \mathrm{~mm}$; UN-DGCR-047, carapace with right cheliped, length $=$ $19.4 \mathrm{~mm}$, width $=25.4 \mathrm{~mm}$.

Comments. Size of carapace, cuticle ornamented with fine granules and multiple short spines on anterolateral margins indicate affinity with Hepatus lineatinus. This species is reported from the Miocene and Pliocene of Panama (Gatun and Escudo de Veraguas formations) (Todd and Collins, 2005).

Superfamily Hexapodoidea, Miers, 1886

Family Hexapodidae Miers, 1886

Genus Palaeopinnixa Vía-Boada, 1966 
Palaeopinixa perornata Collins and Morris, 1976 Figure 4.1

Description. Carapace small, suboval, twice as wide as long; anterior margin two-thirds of maximum width; anterolateral margin concave, twothirds of carapace length; posterolateral margin also concave, one-third the carapace length; posterior margin straight, three-fourths the carapace width; cervical groove deeply impressed; remains of finely granulated cuticle are observed on the steinkern of one specimen; protogastric region distinct; cardiac region with two small tubercles; two small swellings on each side of cardiac region; strong chelipeds with inflated palms, pereiopods 2 to 4 slender.

Material. Two dorsal carapaces and pereiopods found in calcareous concretions UN-DG-CR-64 and UN-DG-GR-65. Las Perdices Formation, Lower Miocene.

Measurements. UN-DG-CR-64, carapace with articulated pereiopods, length $=7.5 \mathrm{~mm}$, width $=$ $11.2 \mathrm{~mm}$; UN-DG-CR-65, carapace with articulated pereiopods, length $=7.2 \mathrm{~mm}$, width $=9.5$ $\mathrm{mm}$.

Comments. The small carapace and traces of finely granular cuticle indicate affinity of the Colombian specimens to Palaeopinixa perornata. This species is reported from the early Miocene of Barbados and Trinidad (Collins and Morris, 1976), Venezuela (Feldmann and Schweitzer, 2004; Aguilera et al., 2010) and Mexico (Vega et al., 2009).

Superfamily Leucosioidea Samouelle, 1819

Family Leucosiidae Samouelle, 1819

Subfamily Philyrinae Leach, 1817

Genus Persephona Leach, 1817

Persephona enigmatica Collins and Todd in Todd and Collins, 2005

Figure $4.2-4.6$

Description. Carapace small, subglobose, posterior portion narrow, with three short posterolateral spines; surface finely granular, ornamented by relatively coarse granules, evenly spaced. Orbits suboval.

Material. One complete and one partial carapaces, UN-DG-CR-048 and UN-DG-CR-049. Tubará Formation, Upper Miocene-Pliocene.

Measurements. UN-DG-CR-048, carapace length $=22.1 \mathrm{~mm}$, width $=18.5 \mathrm{~mm}$; UN-DGCR-049, carapace, length $=8.9 \mathrm{~mm}$, width $=12.5$ $\mathrm{mm}$.

Comments. The finely granulated cuticle and position, carapace shape and position of the central and two posterolateral spines suggest affinity with this species, also reported from the Pliocene Cayo Agua Formation of Panama (Todd and Collins, 2005).

Superfamily Majoidea Samouelle, 1819

Family Majidae Samouelle, 1819

Subfamily Mithracinae MacLeay, 1838

Genus Microphrys H. Milne-Edwards, 1851

\section{Microphrys sp.}

Figure 4.7

Description. Carapace large, broadly pyriform, somewhat depressed, dorsal surface covered by broadly spaced sharp spines, a small marginal spine or tubercle at lateral angle of branchial region.

Material. One incomplete carapace, UNDG-CR-050. Tubará Formation, Upper Miocene-Pliocene.

Measurements. UN-DG-CR-050, carapace length $=45.7 \mathrm{~mm}$, width $=38.8 \mathrm{~mm}$.

Comments. Carapace subpyriform and dorsal carapace ornament of scattered strong spines, suggest affinity to Microphrys. The sole specimen represents the first fossil record for the genus, however more complete specimens are needed in order to offer a detailed specific identification.

Superfamily Portunoidea Rafinesque, 1815 Family Portunidae Rafinesque, 1815 Subfamily Necronectinae Glaessner, 1928 Genus Necronectes A. Milne-Edwards, 1881 
Necronectes proavitus (Rathbun, 1918)

Figure $4.8-4.11$

Description. Carapace medium to large, wider than long, dorsal surface weakly convex transversely, covered by fine granules; carapace regions very weakly developed; frontal margin with four short triangular spines; anterolateral margin convex, longer than posterolateral margin, with eight to nine acute triangular spines; posterolateral margin weakly concave; posterior margin one-fourth the maximum carapace width; thoracic sternites narrow, sternites three and four fused, fourth sternites triangular; lateral sternal process well defined, strongly concave and curving around anterolateral angle of fifth somite, two straight marginal faces distally; fifth sternites separated from anterior sternal plate by distinct groove; abdomen triangular, wider at level of fused somites $3-5$, proximal abdominal somites reduced, carried in subvertical position; buccal cavity rectangular, wider than long; third maxillipeds do not cover axial portion of cavity; no pereiopods or chelipeds preserved.

Material. Five incomplete carapaces, UN-DGCR-052 to UN-DG-GR-056. Tubará Formation, Upper Miocene-Pliocene.

Measurements. UN-DG-CR-052, carapace length $=33.3 \mathrm{~mm}$, width $=54.2 \mathrm{~mm}$; UN-DGCR-053, carapace length $=43.3 \mathrm{~mm}$, width $=$ $62.3 \mathrm{~mm}$; UN-DG-CR-054, carapace length = $23.3 \mathrm{~mm}$, width $=32.3 \mathrm{~mm}$; UN-DG-CR-055, carapace length $=24.1 \mathrm{~mm}$, width $=34.8 \mathrm{~mm}$; UN-DG-CR-056, carapace length $=12.5 \mathrm{~mm}$, width $=22.7 \mathrm{~mm}$.

Comments. Shape and size of carapace, anterolateral margin convex, longer than posterolateral margin, with eight to nine acute triangular spines, are features observed in the new specimens from Colombia that suggest affinity with this species, previously reported from the Miocene of Puerto Rico, Panamá, Venezuela and Ecuador (Roberts, 1975; Schweitzer et al., 2006; Collins et al., 2009; Cáceres et al., 2016).
Genus Scylla De Haan, 1833

$$
\text { Scylla sp. }
$$

Figure 4.12, 4.13

Description. Carapace wider than long, regions poorly defined, carapace covered by fine granules; anterolateral margins curved, with at least seven spines; female abdominal somites 3 - 5 fused, wide. Material. One incomplete carapace, UNDG-CR-051. Tubará Formation, Upper Miocene-Pliocene.

Measurements. UN-DG-CR-051, carapace length $=38.5 \mathrm{~mm}$, width $=28.5 \mathrm{~mm}$.

Comments. The single specimen resembles Scylla costata Rathbun, 1919, from the Oligocene Miocene of Puerto Rico and Haiti, in shape and number of spines on anterolateral margin, but more complete specimens are to be found in order to confirm this affinity.

Subfamily Podophthalminae Dana, 1851 Genus Euphylax Stimpson, 1860

\section{Euphylax maculatus Collins and Todd in Todd and Collins, 2005}

Figure $4.14-4.19$

Description. Carapace transversely subovate, length about two-thirds the maximum width, slightly arched transversely, in longitudinal section it rises to rounded protogastric region; cardiac and branchial regions elevated; orbitofrontal margin equals entire carapace width; rostrum wide, T-shaped and deeply constricted at its base; granulated upper orbital margins; anterolateral margins straight, shorter than sinuous posterolateral margins, with four anterolateral short spines; epibranchial ridge distally bounded by double row of granules; hepatic, mesogastric and lateral parts of the metabranchial lobes are depressed, other lobes weakly tumid; thoracic sternite 3 subhexagonal, weakly concave anteromedially; sternite 4 sub- 


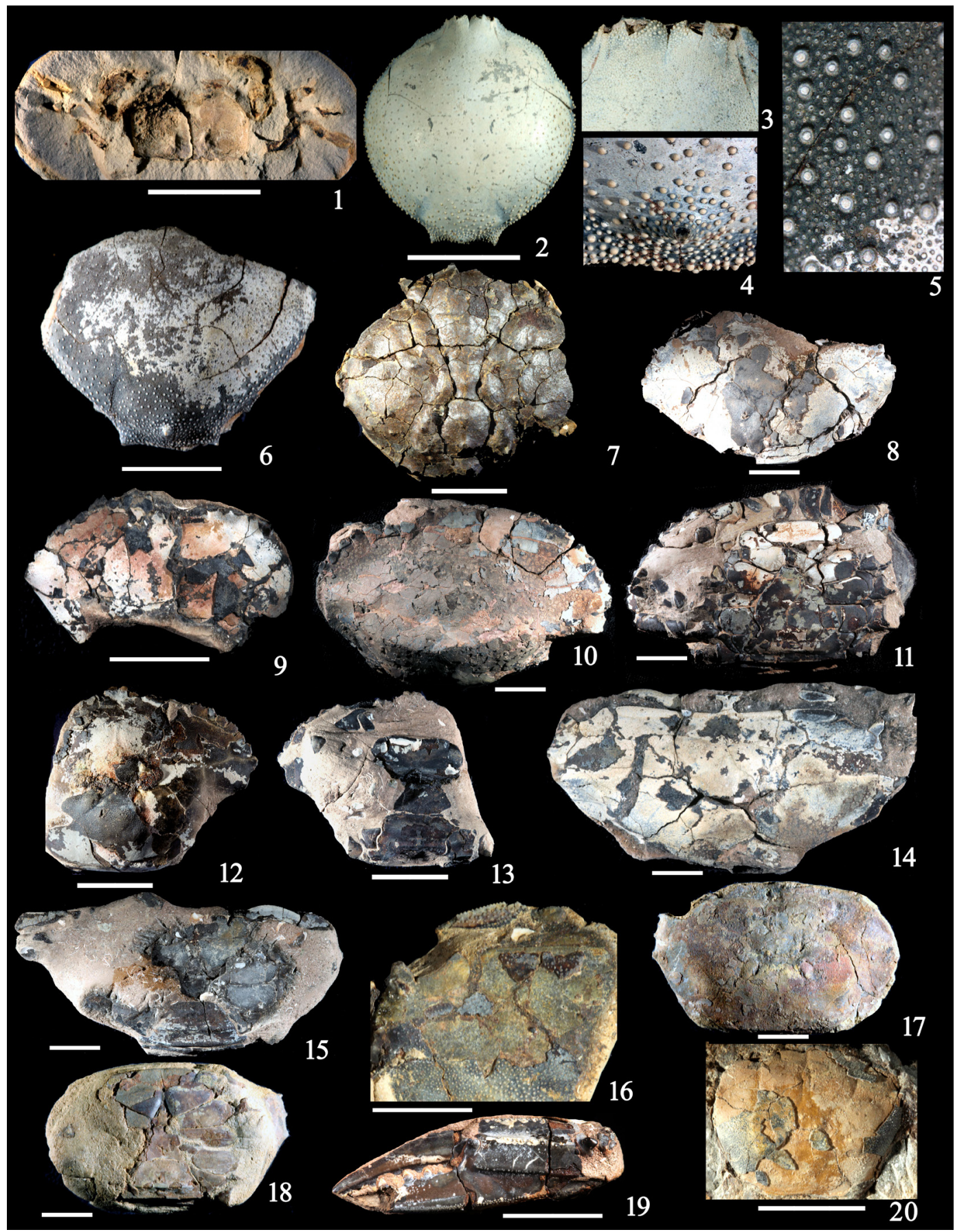

Figure 4 1, Palaeopinnixa perornata Collins and Morris, 1976, Las Perdices Formation, Lower Miocene, dorsal carapace and pereiopods UN-DG-CR-64. 2-6, Persephona enigmatica Collins and Todd in Todd and Collins, 2005, Tubará Formation, Upper MiocenePliocene, 2-4, dorsal carapace and close-ups of anterior and posterior portions of cuticle UN-DG-CR-048; 5, 6, close-up of cuticle and incomplete dorsal carapace UN-DG-CR-049. 7, Microphrys sp., Tubará Formation, Upper Miocene-Pliocene, incomplete dorsal carapace UN-DG-CR-050. 8-11. Necronectes proavitus (Rathbun, 1918), Tubará Formation, Upper Miocene-Pliocene, 8, incomplete dorsal carapace UN-DG-CR-052; 9, small, incomplete dorsal carapace UN-DG-CR-056; 10, 1 , nearly complete dorsal and ventral carapace UN-DG-CR-053. 12, 13, Scylla sp., Tubará Formation, Upper Miocene-Pliocene, incomplete dorsal and ventral carapace UN-DG-CR-051. 14-19, Euphylax maculatus Collins and Todd in Todd and Collins, 2005, Tubará Formation, Upper Miocene-Pliocene, 14, 15, nearly complete dorsal and ventral carapace UN-DG-CR-058; 16, close-up of left anterolateral portion of incomplete carapace, showing dorsal cuticle of left propodus UN-DG-CR-060; 17, 18, incomplete dorsal and ventral carapace UN-DG-CR-061; 19, left chela UN-DG-CR-057. 20, Eurytium sp., Tubará Formation, Upper Miocene-Pliocene, incomplete dorsal carapace UN-DG-CR-063. Scale bars $=10 \mathrm{~mm}$. 
trapezoidal, 3 reminder sternites peltoid, becoming narrow towards posterior portion of carapace; male abdomen triangular, wider at level of fused abdominal somites $3-5$, proximal abdominal somites reduced; female abdomen semicircular, widest at level of somite 3; chelae of similar size and shape, fingers flattened, tricuspidate, dactylus ridged medially, fixed finger ridged along basal margin; dorsal margin of left palm, covered by granules, arranged in longitudinal rows on lateral margins; left palm with three longitudinal keels on outer surface, strong tubercle near junction with carpus.

Material. One complete and four incomplete carapaces UN-DG-CR-057 to UN-DG-CR-061, Tubará Formation, Upper Miocene-Pliocene.

Measurements. UN-DG-CR-057, carapace length $=29.3 \mathrm{~mm}$, width $=46.1 \mathrm{~mm}$; UN-DGGR-058, carapace length $=41.8 \mathrm{~mm}$, width $=$ $66.5 \mathrm{~mm}$; UN-DG-CR-059, carapace length = $20.3 \mathrm{~mm}$, width $=41.4 \mathrm{~mm}$; UN-DG-CR-060, carapace length $=20.1 \mathrm{~mm}$, width $=25.1 \mathrm{~mm}$; UN-DG-CR-061, carapace length $=32.3 \mathrm{~mm}$, width $=38.9 \mathrm{~mm}$.

Comments. Subhexagonal carapace shape, presence of four anterolateral spines and shape and ornamentation of chelae suggest affinity of the Colombian specimens to this species. The species is reported from the Miocene-Pliocene of Panamá and the Pleistocene of Costa Rica (Todd and Collins, 2005).

\section{Superfamily Xanthoidea MacLeay, 1838 \\ Family Panopeidae Ortmann, 1893 \\ Subfamily Panopeinae Ortmann, 1893 \\ Genus Eurytium Stimpson, 1859}

\section{Eurytium sp.}

Figure 4.20

Description. Carapace of medium size, subhexagonal, wider than long, widest at midlength; cuticle with granules of uniform size; anterior margin two-thirds maximum width, orbits semicircular, small, rimmed, front subrectangular, projected beyond orbits, with median groove; anterolateral margin concave, half the length of carapace; posterolateral margin slightly concave, half the length of carapace; posterior margin straight, narrow, one-third carapace width; protogastric region inverted-subtriangular; mesogastric region subpentagonal, with a narrow process that extends only to base of rostrum; urogatric region depressed, narrow; cardiac region subtrapezoidal; mesobranchial region semioval, inclined; metabranchial region a raised platform; cervical groove deeply impressed. Material. One incomplete carapace UNDG-CR-063, Tubará Formation, Upper Miocene-Pliocene.

Measurements. UN-DG-CR-063, carapace length $=19.2 \mathrm{~mm}$, width $=17.9 \mathrm{~mm}$.

Comments. The specimen resembles Eurytium granulosum Schweitzer, Velez-Juarbe, Martinez, Hull, Feldmann, and Santos, 2008, from the Miocene of Puerto Rico, in size, shape and ornament of carapace, but more complete specimens are needed to confirm this affinity.

\section{Conclusions}

The new crustacean assemblage from the Neogene of the Caribbean of Colombia represents an important addition to the fossil decapod diversity of Colombia. The shallow marine to estuarine crustacean assemblage reinforces recent interpretations of shallow facies for the Las Perdices and Tubará formations, previously interpreted as composed by deep marine sediments. Due to the numerous reports on fossil decapods from the Caribbean, it is possible to document a strong paleobiogeographic affinity with Neogene (Miocene-Pliocene) crustacean assemblages from Panama, Puerto Rico and Costa Rica.

\section{Acknowledgments}

Funding for this research was provided by Grupo de Investigación Paleoexplorer (Project "Fossil 
Crustaceans from Colombia"). Special thanks to Luz Stella Bolívar, Liliana Bolívar and Daniela Bermúdez for valuable field assistance. Preliminary preparation of fossils by Mariela Bolívar is highly appreciated. Pedro C. Patarroyo (Universidad Nacional de Colombia) helped with temporary export permits. Our sincere gratitude to Torrey Nyborg, Alessandro Garassino and Àlex Ossó for constructive criticism of the original manuscript. We thank financial support of Universidad Nacional Autónoma de México, Dirección General de Apoyo al Personal Académico, Project PAPIIT-IN103214

\section{References}

Aguilera, O., Rodrigues de Aguilera, D., Vega, FJ., Sánchez-Villagra, M.R., 2010, Mesozoic and Cenozoic decapod crustaceans from Venezuela and related trace-fossil assemblages, 103-129, in Sánchez-Villagra, M.R., Aguilera, O.A., Carlini, A.A. (eds.), Urumaco and Venezuelan Paleontology: The Fossil Record of the Northern Tropics. Indiana University Press, 304 p.

Anderson, F.M., 1927, The marine Miocene deposits of North Colombia: Proceedings of the California Academy of Sciences, Fourth Series, 16, 87-95.

Anderson, F.M., 1929, Marine Miocene and related deposits of north Colombia: Proceedings of the California Academy of Sciences, Fourth Series, 18, 73-213.

Barrios, M., 1960, Algunos moluscos del Terciario Medio de Colombia: Boletín Geológico, 6, 213-306.

Berner, R.A., 1971, Principles of Chemical Sedimentology. New York, McGraw-Hill, $240 \mathrm{p}$.

Berner, R.A., 1981, A new geochemical classification of sedimentary environments: Journal of Sedimentary Petrology, 51, 359-365.
Bhattacharya, J.P., MacEachern, J.A., 2009, Hyperpycnal rivers and prodeltaic shelves: Journal of Sedimentary Research, 79, 184-209.

Bermúdez, H.D., Alvarán, M., Grajales, J.A., Restrepo, L.C., Rosero, J.S., Guzmán, C., Ruiz, E.C., Navarrete, R.E., Jaramillo, C., Osorno, J.F., 2009, Estratigrafía y evolución geológica de la secuencia sedimentaria del Cinturón Plegado de San Jacinto (resumen), in XII Congreso Colombiano de Geología, Paipa, Colombia, 27 p.

Brown, A.P., Pilsbry, H.A., 1913, Fauna of the Gatun Formation, Isthmus of Panama - II: Proceedings of the Academy of Natural Sciences of Philadelphia, 64, 500-519.

Cáceres, C., Rincón, A., Solórzano, A., Sánchez, L., 2016, The first record of the extinct crab Necronectes (Decapoda: Portunidae) in Venezuela: Revista Brasileira de Paleontologia, 19, 145-148.

Coates, L., MacEachern, J.A., 2007, The ichnological signatures of river- and wavedominated delta complexes: differentiating deltaic from non-deltaic shallow marine successions, Lower Cretaceous Viking Formation and Upper Cretaceous Dunvegan Formation, west-central Alberta, 227-254, in MacEachern, J.A., Bann, K.L., Gingras, M.K., Pemberton, S.G. (eds.), Applied Ichnology: Society for Sedimentary Geology (SEPM), Short Course Notes, 52.

Collins, J.S.H., Morris, S.F., 1976, Tertiary and Pleistocene crabs from Barbados and Trinidad: Palaeontology, 19, 107-131.

Collins,J.S.H., Portell, R.W., Donovan, S.K., 2009, Decapod crustaceans from the Neogene of the Caribbean: diversity, distribution and prospectus: Scripta Geologica, 138, 55-111.

Dana, J.D., 1851, Conspectus Crustaceorum quæ in Orbis Terrarum circumnavigatione, Carolo Wilkes e classe Reipublicæ Foederatæ Duce, lexit et descripsit: Proceedings of the Academy of Natural Sciences of Philadelphia, 5, 267-272. 
Dana, J.D., 1852, Conspectus of the Crustacea of the Exploring Expedition under Capt. Wilkes, U.S.N. Macroura: Proceedings of the Academy of Natural Sciences of Philadelphia, 6, 10-28.

De Grave, S., Pentcheff, N.D., Ahyong, S.T., Chan, T.-Y., Crandall, K.A., Dworschak, P.G., Felder, D.L., Feldmann, R.M., Fransen, C.H.J.M., Goulding, L.Y.D., Lemaitre, R., Low, M.E.Y., Martin, J.W., Ng, P.K.L., Schweitzer, G.E., Tan, S.H., Tshudy, D., Wetzer, R., 2009, A classification of living and fossil genera of decapod crustaceans: The Raffles Bulletin of Zoology, Supplement 21, 1-109.

Feldmann, R.M., Schweitzer, C.E., 2004, Decapod Crustaceans from the Lower Miocene of North-Western Venezuela (Cerro La Cruz, Castillo Formation): The Palaeontological Association, Special Papers in Palaeontology, 71, 7-22.

Glaessner, M.F., 1928, Die Dekapodenfauna des österreichischen Jungtertiärs: Jahrbuch der Geologischen Bundesanstalt Wien, 78, 161-219.

Haan, W. de, 1833-1850, Crustacea, in Siebold, P.F. von (ed.), Fauna Japonica sive Descriptio Animalium, Quae in Itinere per Japoniam, Jussu et Auspiciis Superiorum, qui Summum in India Batava Imperium Tenent, Suscepto, Annis 1823-1830 Collegit, Noitis, Observationibus et Adumbrationibus Illustravit, Leiden, Lugduni-Batavorum. $1-243$.

Hyžný, M., Bahrami, A., Klompmaker, A.A., Yazdi, M., Portell, R.W., Neumann, G., 2013, The fossil record of Glypturus (Decapoda: Axiidea: Callianassidae) revisited with additional observations and description of a new species: Swiss Journal of Palaontology, 132, 129-139.

Klompmaker, A.A., Hyžný, M, Portell, R.W., Kowalewski, M., 2016, Growth, inter- and intraspecific variation, palaeobiogeography, taphonomy, and systematics of the Cenozoic ghost shrimp Glypturus: Journal of Systematic Palaeontology, 14, 99-126.

Laenen, B., De Craen, M., 2004, Eogenetic siderite as an indicator for fluctuations in sedimentation rate in the Oligocene Boom Clay Formation (Belgium): Sedimentary Geology, 163, 165-174.

Latreille, P., 1802-1803, Histoire naturelle, générale et particulière, des Crustacés et des Insectes, 3, 1-468.

Leach, W.E., 1817, The Zoological Miscellany, Being descriptions of New or Interesting Animals: London, 3, $151 \mathrm{p}$.

MacEachern, J.A., Bann, K.L., Bhattacharya, J.P., Howell, G.D. Jr., 2005, Ichnology of deltas: organism responses to the dynamic interplay of rivers, waves, storms and tides, in Bhattacharya, B.P., Giosan, L. (eds.), River Deltas - Concepts, Models, and Examples (Society for Sedimentary Geology), Special Publication, 83, 49-86.

MacLeay, W.S., 1838, On the brachyurous decapod Crustacea brought from the Cape by Dr. Smith, in Smith, A., Illustrations of the Annulosa of South Africa; being a portion of the objects of natural history chiefly collected during an expedition into the interior of South Africa, under the direction of Dr. Andrew Smith, in the years 1834, 1835 and 1836; fitted out by "The Cape of Good Hope Association for Exploring Central Africa". London, Smith, Elder, and Co. 53-71.

Manning, R.B., Felder, D.L., 1991, Revision of the American Callianassidae (Crustacea: Decapoda: Thalassinidea): Proceedings of the Biological Society of Washington, 104, 764-792.

Middleton, H.A., Nelson, C.S., 1996, Origin and timing of siderite and calcite concretions: Sedimentary Geology, 103, 93-115. 
Miers, E.J., 1886, Report on the Brachyura collected by H.M.S. Challenger during the years 1873-1876, in Murray, J., Zoology. Wyville Thomson, C. \& J. Murray, Report on the Scientific Results of the Voyage of H.M.S. Challenger During the Years 1873-76 Under the Command of Captain George S. Nares, R.N., F.R.S. and the Late Captain Frank Tourle Thomson, R.N. Vol. 17. Edinburgh, Neill and Company, 1-362.

Milne-Edwards, A., 1881, Note sur quelques Crustacés fossiles des environs de Biarritz: Paris, Annales des Sciences Géologique, 11, 1-8.

Milne Edwards, H., 1851, Observations sur le squelette tégumentaire des Crustacés décapodes, et sur la morphologie de ces animaux: Annales des Sciences Naturelles, 3e série, 16, 221-291.

Molinares, C.E., Martínez, J.I., Fiorini, F., Jaramillo, C., 2007, Ambientes de acumulación y foraminíferos bentónicos de la Formación Tubará (Plioceno del Valle Inferior del Magdalena): Boletín de Geología (Colombia), 29, 29-38.

Ortmann, A.E., 1892, Die Decapoden-Krebse des Strassburger Museums, mit besonderer Berücksichtigung der von Herrn Dr. Döderlein bei Japan und bei den LiuKiu-Inseln gesammelten und zur Zeit im Strassburger Museum aufbewahrten Formen. IV. Die Abtheilungen Galatheidea und Paguridea: Zoologische Jahrbücher. Abteilung für Systematik, Geographie und Biologie der Thiere, 6, 241-326.

Ortmann, A.E., 1893, Die Decapoden-Krebse des Strassburger Museums, mit besonderer Berücksichtigung dervonHerrnDr. Döderlein bei Japan und bei den Liu-Kiu-Inseln gesammelten und zur Zeit im Strassburger Museum aufbewahrten Formen. VII. Theil. Abtheilung: Brachyura (Brachyura genuina Boas) II. Unterabtheilung: Cancroidea, 2. Section: Cancrinea, 1. Gruppe: Cyclometopa:
Zoologische Jahrbücher. Abteilung für Systematik, Geographie und Biologie der Thiere, 7, 411-495.

Pilsbry, H.A., Brown, A.P., 1917, Oligocene fossils from the neighborhood of Cartagena, Colombia, with notes on some Haitian species: Proceedings of the Academy of Natural Sciences of Philadelphia, 69(1), 32-41.

Pineda-Salgado, G., Bermúdez, H.D., Vega, F.J., Mora, A., 2013, Nuevos aportes al conocimiento del registro paleontológico del Neógeno de la parte norte del Cinturón Plegado de San Jacinto, Colombia (resumen), in Memorias del XIV Congreso Colombiano de Geología: Bogotá D.C., Colombia, 331 p.

Rafinesque, C.S., 1815, Analyse de la Nature, ou Tableau de l'Univers et des Corps Organisés: Palermo, L'Imprimerie de Jean Barravecchia, $224 \mathrm{p}$.

Rathbun, M.J., 1918(1919), Decapod crustaceans from the Panama region, in Vaughan, T.W. (ed.), Contributions to the geology and paleontology of the Canal Zone, Panama and geologically related areas in Central America and the West Indies: United States National Museum Bulletin, 103, 123-184.

Rathbun, M.J., 1919, West Indian Tertiary decapod crustaceans, in Vaughan, T.W. (ed.), Contributions to the geology and paleontology of the West Indies: Carnegie Institution of Washington Publication, 291, 159-184.

Roberts, T.R., 1975, Characoid fish teeth from Miocene deposits in the Cuenca Basin, Ecuador: Journal of Zoology, 175, 259-271.

Saint Laurent de, M., 1979, Sur la classification et la phylogénie des Thalassinides: définition de la superfamille des Axioidea, de la sousfamille des Thalassininae et deux genres nouveaux (Crustacea Decapoda): Paris, Comptes Rendus Hebdomadaires des Séances de l'Académie des Sciences, (d)288, 1395-1397. 
Sakai, K., 1988, A new genus and five new species of Callianassidae (Crustacea: Decapoda: Thalassinidea) from northern Australia: The Beagle, Records of the Northern Territory Museum of Arts and Sciences, 5, 51-69.

Samouelle, G., 1819, The entomologist's useful compendium; or an introduction to the knowledge of British insects, comprising the best means of obtaining and preserving them, and a description of the apparatus generally used; together with the genera of Linné, and the modern method of arranging the classes Crustacea, Myriapoda, Spiders, Mites and Insects, from their affinities and structure, according to the views of Dr. Leach. Also an explanation of the terms used in entomology; a calendar of the times of appearance and usual situations of near 3,000 species of British insects; with instructions for collecting and fitting up objects for the microscope, London, $496 \mathrm{p}$.

Schweitzer, C.E., Iturralde-Vinent, M., Hetler, J.L., Velez-Juarbe, J., 2006, Oligocene and Miocene decapods (Thalassinidea and Brachyura) from the Caribbean: Annals of Carnegie Museum, 75(2), 111-136.

Schweitzer, C.E., Velez-Juarbe, J., Martinez, M., Collmar Hull, A., Feldmann, R.M., Santos, H., 2008, New Cretaceous and Cenozoic Decapoda (Crustacea: Thalassinidea, Brachyura) from Puerto Rico, United States Territory: Bulletin of the Mizunami Fossil Museum, 34, 1-15.

Stimpson, W., 1858, Prodromus descriptionis animalium evertebratorum, quae in Expeditione ad Oceanum Pacificum Septentrionalem, a Republica Federata missa, Cadwaladaro Ringgold et Johanne Rodgers Ducibus, observavit et descripsit. Pars VII. Crustacea Anomura: Proceedings of the Academy of Natural Sciences of Philadelphia, 10, 225-252.
Stimpson, W., 1859, Notes on North American Crustacea, No. I: Annals of the Lyceum of Natural History of New York, 7, 49-93.

Stimpson, W., 1860, Notes on North American Crustacea, No. II: Annals of the Lyceum of Natural History of New York, 7, 177-246.

Stimpson, W., 1866, Descriptions of new genera and species of Macrurous Crustacea from the coasts of North America: Proceedings of the Chicago Academy of Sciences, 1, 46-48.

Todd, A.J., Collins, J.S.H., 2005, Neogene and Quaternary crabs (Crustacea, Decapoda) collected from Costa Rica and Panama by members of the Panama Paleontology Project: Bulletin of the Mizunami Fossil Museum, 32, 53-85.

Vega, F.J, Bermúdez, H.D., 2015, Primer reporte de crustáceos decápodos en el Neógeno del Cinturón Plegado de San Jacinto, Caribe colombiano (resumen), in Memorias del XV Congreso Colombiano de Geología, Bucaramanga, Colombia, 658-662.

Vega, F.J., Nyborg, T., Coutiño, M.A., Solé, J., Hernández-Monzón, O., 2009. Neogene Crustacea from Southeastern Mexico: Bulletin of the Mizunami Fossil Museum, 35, 51-69.

Vía-Boada, L., 1966, Pinnixa (Palaeopinnixa) mytilicola nuevo braquiuro fósil en el Mioceno marino des Valles (Barcelona): Acta Geológica Hispánica, 1, 1-4.

Weisbord, N.E., 1929, Miocene Mollusca of Northern Colombia: Bulletin of American Paleontology, 14, 1-310. 